\title{
The September 2017 flood in Elbląg (Poland) in perspective
}

\author{
Roman Konieczny \\ Institute of Meteorology and Water Management - National Research Institute, Podleśna 61, 01-673 Warsaw, Poland, \\ e-mail: rkoniec@gmail.com
}

Iwona Pińskwar, Zbigniew Kundzewicz

Institute for Agricultural and Forest Environment of Polish Academy of Sciences, Bukowska 19, 60-809 Poznań, Poland, e-mail: iwona.pinskwar@isrl.poznan.pl,kundzewicz@yahoo.com

\begin{abstract}
On the morning of 18 September 2017, the center of the city of Elbląg in northern Poland was inundated by the rapidly rising waters of the Kumiela River, resulting in considerable damage and chaos in the city. The present paper provides information about this event, which was caused by intense precipitation lasting two days. We put this individual event in perspective by examining the climate track in the observation and projection of flood hazard through analyzing changes in temperature, precipitation and intense precipitation. We also examine the non-climatic factors of flood risk, such as spatial development and river regulation. Further, we pose the question of whether actions aimed at flood risk reduction, predominantly by way of structural defenses in the catchment of the Kumiela River, really reduce the flood risk in Elbląg. We also offer more general remarks pertaining to flood risk reduction in Poland, primarily based on technical measures, and we unveil the shortcomings of the current flood risk management system in Poland. In the social consciousness, the structural flood defense strategy has become the norm of thinking in terms of methods for reducing the effects of floods in Poland, but this does not always contribute to reducing flood damage either locally or nationally. We refer to some good examples of preparedness for urban inundations caused by heavy precipitation in other cities.
\end{abstract}

Keywords: flash flood, heavy precipitation, flood risk reduction, Elbląg, Poland

Submitted 6 February 2018, revised 5 May 2018, accepted 19 June 2018

\section{Introduction}

On the morning of 18 September 2017, the center of the city of Elbląg (121 191 inhabitants; GUS 2017) in northern Poland was inundated by the rapidly rising waters of the Kumiela River. According to the IMGW-PIB SYNOP station Elbląg-Milejewo, located approximately $10 \mathrm{~km}$ east of Elblag, the $24 \mathrm{~h}$ precipitation total from 17.09.2017 18 UTC to 18.09 .201718 UTC reached $90 \mathrm{~mm}$. Storm clouds were present over the Elbląg Highlands for two whole days, and a considerable part of the precipitation fell onto the Kumiela catchment, generating a flash urban flood. This amount of rainfall in urban areas in the region has led to other violent events. For instance, on 09.07.2001, precipitation of $80 \mathrm{~mm}$ within only 4 hours in the area of the Radunia Channel caused a rapid increase in river flow and a devastating flash flood, which hit the city of Gdańsk (Majewski 2016).

Several streets were flooded in Elbląg on 18 September 2017 , resulting in considerable chaos and traffic jams in the city. There was water in the cellars of houses at streets including Związku Jaszczurczego St., Grunwaldzka St.,
Wyspiański St. and Fromborska St. The water level on the streets reached up to $0.5 \mathrm{~m}$. A private hospital, located at Związku Jaszczurczego st., and in particular its electricity generators and dialysis pumps, were in jeopardy.

The preliminary estimates made by the City Office show that some twenty educational establishments suffered losses. Basements in 26 houses were inundated, communication infrastructure was destroyed, and some 80 individuals requested help. According to the fire brigade records, its units intervened 52 times during those days. The interventions mainly concerned residential buildings, but also public facilities and infrastructure. The flood caused damage mainly to private owners (37 facilities), but also in buildings owned by the commune and other entities (companies, associations, etc.). The city estimated losses at the level of PLN 14 million (EUR 3.37 million).

More than 450 firefighters and policemen participated in the action during the flood. The army helped with the placement of sand bags on the dikes ${ }^{1}$.

\footnotetext{
${ }^{1}$ A gallery of photos can be found at https://info.elblag.pl/galeria, 5510,1,80,Powodz-w-Elblagu.html\#szlak
} 
The Kumiela is a small river with a length of almost $17 \mathrm{~km}$. Its catchment (ca. $40 \mathrm{~km}^{2}$ in area) is largely located in the Elbląg Highlands, which gives the river the nature of a piedmont river, with considerable bottom slope. The difference in elevation over the upstream reach of the Kumiela $(11 \mathrm{~km})$ is 150 meters (i.e. the mean bottom slope in nearly $1.4 \%$ ), so river runoff can be violent after heavy rains.

The Kumiela River is known for having caused serious flood hazard in the past. The violent increases of the water level in the river and its uncontrollable nature explain why the inhabitants of Elbląg call it "a savage river".

In the end of August 1924, due to intense rainfall, the Kumiela inundated a large area of Elbląg (then Elbing in the Western Prussia Province, Germany), including the railway station. Also the present streets, Grunwaldzka St. and Związku Jaszczurczego St., as well as many others, were under water.

Another flood inundated the city a year later, affecting the residents of the same streets. These floods mobilized the city authorities to undertake flood protection activities. The embankments were built in the area of the mouth of the river, the bed was covered with stone slabs, the bridges on the Kumiela River were raised, and the river was dredged. These activities resulted in deepening of the river by $1 \mathrm{~m}$. However, this did not protect the city from floods. The last one before 2017 took place in 2007.

In the present paper, we examine the observed and projected climate track in relation to flood hazard (changes in temperature, precipitation and intense precipitation, in particular). Also, the non-climatic factors of flood risk are analyzed, such as spatial development and river regulation. Then, we pose the question of whether actions aimed at flood risk reduction, with structural defenses in the catchment of the Kumiela River, really reduce flood risk in Elbląg. More general remarks pertaining to the flood risk reduction strategy in Poland are also offered.

Using the example of a flood in Elbląg, the aim of the analysis presented in the article is to show projected changes in rainfall hazards as well as problems related to the preparation of local communities for current and future floods. This is a case study that illustrates a typical situation for many cities in Poland.

\section{Factors driving changes in flood risk}

\subsection{Ubiquitous warming}

A strong warming signal has been detected, being actually ubiquitous at every scale from global to continental, regional to local, and this is likely related to changes in precipitation.
The annual mean areal temperature in Poland in the interval $1951-2008$ was $7.9^{\circ} \mathrm{C}$. It has increased at the rate of ca. $0.24^{\circ} \mathrm{C} / 10$ years, and the change is statistically significant (Wibig, Jakusik 2012). Winter, with a mean temperature $-1.2^{\circ} \mathrm{C}$, is the season when temperature increases the most: $0.38^{\circ} \mathrm{C} / 10$ years. Spring (mean temperature $7.4^{\circ} \mathrm{C}$ ) has warmed at the rate of $0.36^{\circ} \mathrm{C} / 10$ years, summer $\left(17.1^{\circ} \mathrm{C}\right)$ by ca $0.17^{\circ} \mathrm{C} / 10$ years, and autumn $\left(8.4^{\circ} \mathrm{C}\right)$ by $0.06^{\circ} \mathrm{C} / 10$ years, whereas the latter change was statistically insignificant (Wibig, Jakusik 2012). Owczarek and Filipiak (2016) analyzed the air temperature in Poland at 18 meteorological stations for 1951-2015 and concluded that the mean temperature increased by $0.18-0.34^{\circ} \mathrm{C} /$ 10 years, that is the mean annual air temperature increased by $1.1-2.2^{\circ} \mathrm{C}$ since 1951 . Warming is also observed in extreme temperatures in Poland. The increase in intensity and frequency of heat waves is noted. The number of hot days in summer and the number of tropical nights in a year has significantly increased. In turn, cold extremes have become less frequent, and decreases in the number of extremely cold days in a year have been observed. Also, the maximum number of consecutive very cold and extremely cold days in a year has decreased. However, the trends are not ubiquitous, and natural variability is strong (Graczyk, Kundzewicz 2014; Graczyk et al. 2017; Wibig 2018).

Temperature records at Elbląg (54.16 N, $19.43 \mathrm{E}$; $40 \mathrm{~m}$ a.s.1.) are available from 01.01 .1951 to 31.03 .2013 . Next, the station was relocated about $10 \mathrm{~km}$ to the northeast to Elbląg-Milejewo (54.22 N, 19.54 E; 189 m a.s.1.)2. The annual mean temperature for the station Elblacg for $1951-2012$ was $7.82^{\circ} \mathrm{C}$. The rate of increase of annual mean temperature was $0.22^{\circ} \mathrm{C} / 10$ years, and the change was found to be statistically significant at the level of 0.05 using the non-parametric Mann-Kendall test with the help of the Hydrospect software 2.0 (Radziejewski, Kundzewicz 2000). The five warmest years occurred in 2000 (mean annual temperature: $\left.9.37^{\circ} \mathrm{C}\right), 1989\left(9.31^{\circ} \mathrm{C}\right)$, $2007\left(9.26^{\circ} \mathrm{C}\right), 1990\left(9.22^{\circ} \mathrm{C}\right)$, and $2002\left(9.19^{\circ} \mathrm{C}\right)$. For the examined period of 1951-2012, the strongest warming (statistically significant) was detected during spring: $0.39^{\circ} \mathrm{C} / 10$ years. Table 1 presents values of annual and seasonal temperatures for each decade, as well as rates of change, for 1951-2012. The last two decades, 1991-2000 and 2001-2012 (12 years), were considerably warmer than the previous ones in terms of annual and seasonal mean temperature, except for autumn in 1991-2000.

\footnotetext{
${ }^{2}$ https://meteomodel.pl/BLOG/stacje-meteo-elblag-milejewo/
} 
Table 1. Mean values of annual and seasonal temperatures in Elbląg for particular decades, as well as rates of change, over 1951-2012 (last decade extended to 2001-2012); the changes marked in bold are statistically significant

\begin{tabular}{|l|c|c|c|c|c|c|c|}
\hline \multirow{2}{*}{ Mean temperature } & \multicolumn{5}{|c|}{ Mean temperature for decades $\left[{ }^{\circ} \mathrm{C}\right]$} & \multirow{2}{*}{$\begin{array}{c}\text { Change }{ }^{\circ} \mathrm{C} / 10 \text { years } \\
{\left[{ }^{\circ} \mathrm{C}\right]}\end{array}$} \\
\cline { 2 - 8 } & $1951-1960$ & $1961-1970$ & $1971-1980$ & $1980-1990$ & $1991-2000$ & $2001-2012$ & $\mathbf{0 . 2 2}$ \\
\hline Annual & 7.44 & 7.26 & 7.55 & 7.87 & 8.15 & 8.47 & 0.27 \\
\hline Winter DJF & -1.58 & -2.90 & -1.04 & -1.05 & -0.41 & -0.90 & $\mathbf{0 . 3 9}$ \\
\hline Spring MAM & 6.18 & 6.57 & 6.79 & 7.65 & 7.82 & 8.12 & $\mathbf{0 . 1 9}$ \\
\hline Summer JJA & 16.70 & 16.65 & 16.48 & 16.42 & 17.03 & 17.80 & 0.07 \\
\hline Autumn SON & 8.31 & 8.79 & 7.97 & 8.47 & 8.10 & 9.01 & \\
\hline
\end{tabular}

\subsection{Observed changes in precipitation}

The mean annual areal precipitation total for Poland for 1961-2009 was $623.7 \mathrm{~mm}$, and the observed changes in total precipitation differed between regions (Wibig, Jakusik 2012). For Elbląg, the mean annual precipitation total for 1951-2012 was $666.1 \mathrm{~mm}$, and the trend was increasing but statistically insignificant (Tab. 2). Total precipitation was increasing for all seasons, but these changes were found to be statistically significant only for winter and spring. In 1991-2012, annual mean, winter and spring precipitation totals were higher than for previous decades, whereas the highest mean summer total occurred in 1951-1960. However, the maximum annual and seasonal precipitation totals were observed in 1960, 1967, 1970 and 1992. The new records for annual and autumn precipitation, observed in 2017, are biased by the nonhomogeneity of the sample. In general, precipitation records from the new station Elbląg-Milejewo (10 km away) are much higher than those at the previous location.

It follows from climatological premises that the potential for intense precipitation increases with warming, as per the Clausius-Clapeyron law describing the increase in the saturation vapor pressure of the warmer atmosphere. It is very likely that global near-surface and tropospheric air humidity has increased since the 1970s (IPCC 2014). This warming-induced intensification of the water cycle should have a general impact on the increase in the frequency and intensity of heavy precipitation events. However, the detection of change in heavy precipitation records is a difficult task because of fluctuations at nearly all temporal and spatial scales. Hence, the change detection studies published so far do not show a ubiquitous and consistent signal in heavy precipitation at larger (continental, regional, or national) scales.

Extreme precipitation shows irregular trends, depending on regions. Hartmann et al. (2013) stated that the number of stations with increases in extreme precipitation in some regions of Europe exceeds those with decreases, but an assessment of changes is hampered by regional and seasonal variability. Studies conducted in Poland also show inconsistent results, depending on the study interval, datasets used, and calculated indices. According to Lorenc and Olecka (2006), the number of days with intense precipitation ( $\geq 10 \mathrm{~mm} /$ day) was increasing over a large area of Poland during 1971-2002. Also, the number of days with very intense precipitation ( $\geq 20 \mathrm{~mm} /$ day) increased. Łupikasza (2017) studied extreme precipitation using the $95^{\text {th }}$ percentile as the threshold. She revealed increasing trends, especially for spring and mainly in the northern part of Poland during winter. For summer and autumn records, decreasing trends were predominant. Pińskwar et al. (2018) compared the annual indices of extreme precipitation of two periods, colder 1961-1990 and warmer

Table 2. Mean values of annual and seasonal precipitation totals for individual decades, rates of change for 1951-2012, and absolute maximum with the year of occurrence; the changes marked in bold are statistically significant; the highest mean values for the decades are underlined; data for the new meteorological station Elbląg-Milejewo are marked in italic

\begin{tabular}{|c|c|c|c|c|c|c|c|c|c|}
\hline \multirow{2}{*}{$\begin{array}{l}\text { Precipitation } \\
\text { total }\end{array}$} & \multicolumn{6}{|c|}{ Mean precipitation total for decades [mm] } & \multirow{2}{*}{$\begin{array}{c}\text { Change } \\
\mathrm{mm} / 10 \text { years }\end{array}$} & \multirow{2}{*}{ Year } & \multirow{2}{*}{$\begin{array}{c}\text { Maximum } \\
{[\mathrm{mm}]}\end{array}$} \\
\hline & $1951-1960$ & $1961-1970$ & $1971-1980$ & $1980-1990$ & $1991-2000$ & $2001-2012$ & & & \\
\hline Annual & 660.5 & 636.6 & 634.8 & 670.0 & 687.4 & $\underline{700.4}$ & 12.4 & $\begin{array}{l}1960 \\
2017\end{array}$ & $\begin{array}{r}939.3 \\
1222.0\end{array}$ \\
\hline Winter DJF & 120.1 & 101.7 & 99.9 & 129.2 & $\underline{134.7}$ & 130.7 & 5.0 & 1967 & 200.4 \\
\hline Spring MAM & 104.3 & 132.3 & 103.3 & 110.3 & $\underline{139.9}$ & 135.5 & 5.5 & 1970 & 216.9 \\
\hline Summer JJA & 254.9 & 220.4 & 252.2 & 248.3 & 211.7 & 253.7 & 0.9 & 1960 & 511.5 \\
\hline Autumn SON & 197.5 & 179.3 & 180.0 & 183.3 & $\underline{199.2}$ & 184.4 & 1.1 & $\begin{array}{l}1992 \\
2017\end{array}$ & $\begin{array}{l}343.3 \\
499.4\end{array}$ \\
\hline
\end{tabular}


Table 3. Mean values of indices of extreme precipitation for Elbląg for particular decades from 1951-2012, the rate of change, and absolute maximum with date of occurrence; no change was statistically significant; the highest mean values for the decades are underlined; data for the new meteorological station Elbląg-Milejewo are marked in italic

\begin{tabular}{|c|c|c|c|c|c|c|c|c|c|c|}
\hline \multirow{2}{*}{$\begin{array}{l}\text { Index of extreme } \\
\text { precipitation }\end{array}$} & \multirow{2}{*}{ Unit } & \multicolumn{6}{|c|}{ Mean value of index for decades } & \multirow{2}{*}{$\begin{array}{l}\text { Change/ } \\
10 \text { years }\end{array}$} & \multirow{2}{*}{$\begin{array}{l}\text { Date or year } \\
\text { (last day) }\end{array}$} & \multirow{2}{*}{ Max } \\
\hline & & $1951-1960$ & $1961-1970$ & $1971-1980$ & $1980-1990$ & $1991-2000$ & 2001-2012 & & & \\
\hline $\operatorname{Max} 24 \mathrm{~h}$ & $\mathrm{~mm}$ & 35.3 & 39.5 & 40.3 & 37.2 & 43.3 & 33.6 & -0.4 & 1992-09-06 & 83.8 \\
\hline Max 3 day & $\mathrm{mm}$ & 50.8 & 51.6 & 61.1 & 58.4 & 63.4 & 50.2 & 0.4 & 1992-09-08 & 128.4 \\
\hline Max 5 day & $\mathrm{mm}$ & 63.9 & 60.0 & 71.6 & 68.5 & 72.7 & 64.9 & 0.7 & $1960-07-28$ & 129.6 \\
\hline $\begin{array}{l}\text { No. of days } \\
P \geq 10 \mathrm{~mm}\end{array}$ & days & 16.8 & 16.5 & 16.0 & 16.3 & 17.0 & $\underline{18.8}$ & 0.4 & 1970 & 33 \\
\hline $\begin{array}{l}\text { No. of days } \\
P \geq 20 \mathrm{~mm}\end{array}$ & days & $\underline{4.2}$ & 3.7 & 4.0 & 3.5 & 3.1 & 2.9 & -0.2 & 1960 & 12 \\
\hline Annual $P 95$ & $\mathrm{~mm}$ & 17.4 & 15.9 & 16.6 & 16.9 & 15.6 & 15.6 & -0.2 & 1960 & 28.1 \\
\hline$P 95 \mathrm{DJF}$ & $\mathrm{mm}$ & 9.4 & 7.8 & 8.0 & 9.5 & $\underline{9.8}$ & 9.3 & 0.2 & 1993,2015 & 14.0 \\
\hline$P 95$ MAM & $\mathrm{mm}$ & 12.0 & $\underline{13.2}$ & 10.8 & 11.1 & 13.2 & 12.6 & 0.1 & 1959 & 30.7 \\
\hline$P 95 \mathrm{JJA}$ & $\mathrm{mm}$ & 21.3 & 20.2 & $\underline{23.2}$ & 21.4 & 18.6 & 21.1 & -0.2 & $\begin{array}{l}1986, \\
2013\end{array}$ & $\begin{array}{l}32.5 \\
44.2 \\
\end{array}$ \\
\hline P95 SON & $\mathrm{mm}$ & 17.2 & 15.1 & 13.7 & 15.5 & 19.7 & 13.7 & -0.1 & 1992 & 33.9 \\
\hline
\end{tabular}

1991-2015, and they showed that most of the statistical indices, such as the $25^{\text {th }}$ and $75^{\text {th }}$ percentiles, median, mean and maximum, were higher during the last 25 years. Also, increasing trends were more numerous than decreasing trends, but many changes were weak and statistically insignificant. Updating analyses with the most recent data is necessary in order to improve understanding of the changes.

Table 3 presents the mean values of indices of extreme precipitation for Elbląg for particular decades from 19512012, as well as the rate of change. None of the trends are statistically significant. The trend for maximum daily precipitation was decreasing, but those for maximum 3-day and 5-day precipitation were increasing. The number of days with intense precipitation $(\geq 10 \mathrm{~mm} /$ day $)$ increased during the last four decades. However, the number of days with very intense precipitation ( $\geq 20 \mathrm{~mm} /$ day), as well as the annual P95 $\left(95^{\text {th }}\right.$ percentile of precipitation for days with precipitation $\geq 1 \mathrm{~mm} /$ day) decreased. The latter index was increasing for winter and spring, and decreasing for summer and autumn. The absolute maximum occurred for three indices in 1960 and for another three in 1992.

\subsection{Projected changes}

Climate-model based projections for future flood risk in the warmer world are generally ambiguous (cf. Kundzewicz et al. 2017). Globally, heavy precipitation indices (maximum 1-day and maximum 5-day precipitation totals) are projected to become higher than at present (Hay et al. 2016).

Observed changes in temperature and precipitation for 2001-2012 in comparison with 1971-2000 and projections for 2100-2071 in comparison with 1971-2000 are shown in Table 4. Projections of temperature and precipitation are results of the project CHASE-PL ${ }^{3}$ within the Polish-Norwegian Research Programme. To assess future changes, the dynamical downscaling (DD) experiment with nine regional climate model simulations from the EURO-CORDEX experiment (Jacob et al. 2014) was used for two targeted representative concentration pathways: $4.5 \mathrm{~W} \cdot \mathrm{m}^{-2}$ and $8.5 \mathrm{~W} \cdot \mathrm{m}^{-2}(\mathrm{RCP} 4.5$ and $\mathrm{RCP} 8.5$, respectively; cf. Van Vuuren et al. 2011).

According to projections, mean temperature in Elbląg will increase in both scenarios and will be higher under RCP8.5. The highest increase in temperature is projected for winter, for both RCPs. Also, the future precipitation total for Elbląg is expected to increase. The highest increase is projected for spring, for both RCPs. The observed change in precipitation total for winter at present (2001-2012 vs 1971-2000) is already higher (7.8\%) than that projected for RCP4.5 (7.1\%). The highest increase in extreme precipitation (P95) is observed for spring $(7.8 \%)$ and for winter $(2.1 \%)$, and decreases are noted for summer and autumn. In the future, extreme precipitation is projected to increase for all seasons, especially in winter and spring (20-30\%).

\subsection{Non-climatic factors driving flood risk}

In the search for flood generation factors, it is necessary to examine non-climatic conditions affecting flood risk in the Kumiela River basin, which are related to the hydrological, terrestrial, and socio-economic systems.

\footnotetext{
${ }^{3}$ Climate change impact assessment for selected sectors in Poland; www.chase-pl.pl; http://climateimpact.sggw.pl/map/proj/
} 
Table 4. Observed changes of temperature and precipitation for 2001-2012 in comparison with 1971-2000, and projections for 2100-2071 in comparison with 1971-2000

\begin{tabular}{|l|c|c|c|}
\hline \multirow{2}{*}{ Index } & Change 2001-2012 & Projections for 2100-2071 vs 1971-2000 \\
\cline { 2 - 4 } & Mean 1971-2000 & DD RCP4.5 & DD RCP8.5 \\
\hline Annual & 0.6 & 2.2 & 3.7 \\
\hline DJF & -0.1 & 2.6 & 4.6 \\
\hline MAM & 0.7 & 2.3 & 3.4 \\
\hline JJA & 1.2 & 1.7 & 3.2 \\
\hline SON & 0.8 & 2.0 & 3.4 \\
\hline \multicolumn{5}{|c|}{ Precipitation total-change in \% } \\
\hline Annual & 5.5 & 8.2 & 14.8 \\
\hline DJF & 7.8 & 7.1 & 18.9 \\
\hline MAM & 14.9 & 17.9 & 34.4 \\
\hline JJA & 6.9 & 8.1 & 4.9 \\
\hline SON & -1.7 & 8.9 & 19.1 \\
\hline \multicolumn{5}{|c|}{ Extreme precipitation } \\
\hline No. of days $P \geq 10$ mm (change in days) & 2.4 & $2-4$ & $4-6$ \\
\hline Annual $P 95$ (change in \%) & -4.3 & $0-10$ & $10-20$ \\
\hline
\end{tabular}

Source: Pińskwar, Dobler 2018; Mezghani et al. 2017; http://climateimpact.sggw.pl/map/proj/

One of the important factors allowing the system to cope with the smaller and medium floods is the natural water storage capacity in the catchment. The analysis of the catchment area indicates that the sealing of its urbanized parts has been carried out. However, most of the catchment area, consisting of arable land, forests and undeveloped land, is not sealed ${ }^{4}$, cf. Fig. 1. In brief, the water storage potential of the upper part of the catchment is still large, but it is much smaller in the lower part of the catchment. In the spatial development study for the town of Elbląg, the functionality of the upper part of the catchment was

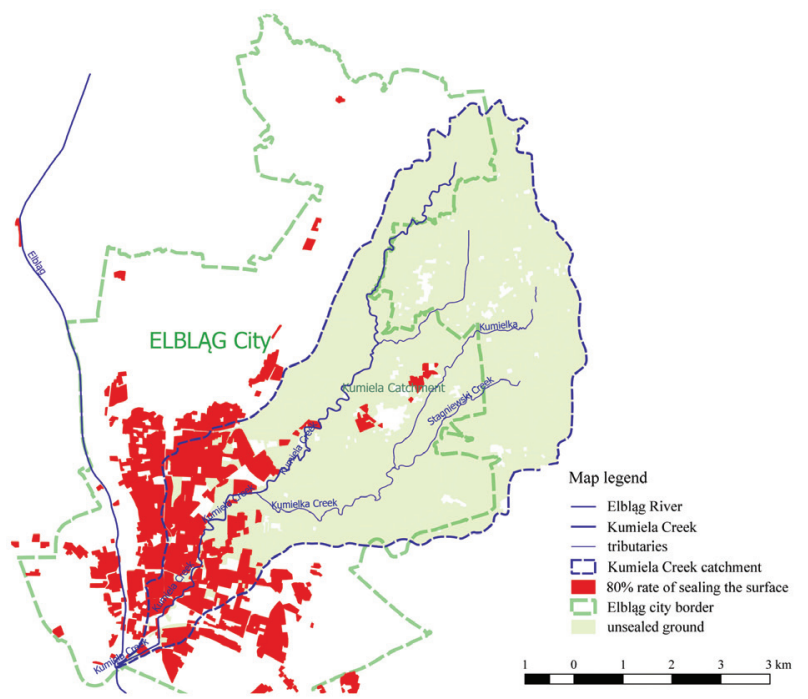

Fig. 1. Development of the catchment of the Kumiela River (this study)

\footnotetext{
${ }^{4}$ https://www.eea.europa.eu/data-and-maps/data/urban-atlas
}

reserved for agriculture and forestry as well as green areas. However, in the central part of the drainage basin, housing development is planned, and this will undoubtedly lead to a partial sealing of the catchment.

Intentional activities for flood risk reduction undertaken in the Kumiela River basin, such as river regulation, are discussed in Chapter 3.

\section{Flood risk management - reduction of flood hazard}

The floods that affected European countries in the last three decades have inspired discussions on ways to reduce the adverse effects of floods, and consequently for setting the substantive framework and the time for its implementation throughout the European Union (EU). The EU Floods Directive, which was established and adopted by the European Parliament in 2007 (2007/60/EC), led to a clear change in the paradigm of thinking about reducing the effects of floods. The Directive calls for integration of many activities from various fields, such as engineering, spatial planning, environmental protection, and crisis management. Moreover, it points out that in order to achieve the best results, not only the state administration, but also local authorities must be included in the process, as well as endangered owners of facilities and entrepreneurs. Everyone can make a meaningful and important contribution to reducing the risk in their areas.

The Directive conveys a simple message. It recommends drawing up flood risk management plans for floodprone areas, based on well-prepared flood hazard and 
flood damage maps. Generally speaking, the concept of flood risk according to the Directive integrates two elements: the probability of flood occurrence and the adverse consequences of flooding. Taking this as a basis, it is now assumed that the flood risk is driven by at least three factors: the probability of a flood (hazard), existence of people and damage potential in the flood-prone area (exposure), and the likely adverse impact of flooding (vulnerability). An effective action plan should take into account all of these components.

It is worth examining the activities undertaken in Elbląg and in the Pomeranian region in light of the EU Floods Directive.

Several measures have been taken or are being planned for Elbląg, aimed at the reduction of flood risk. This applies to the planned and the implemented regulation of the watercourse and the planned construction of a storage reservoir on the Srebrny Stream, a tributary to the Kumiela River.

\subsection{River regulation}

The Kumiela River, flowing through Elbląg, has been managed, transformed, drained and regulated over centuries, especially in its lower reaches, where it has served many useful functions. There were some ten water mills, a forge, a foil and a paper mill on the river, and a water retention pond was associated with each mill. The river provided water to almost 100 wells and waterworks, as well as to the city's moat. In result, for practical reasons, the river had several beds.

When the functions of the river, as mentioned above, ended, some troughs were covered up. At present, the river is regulated (Fig. 2) from its mouth to the River Elbląg to the city borders (i.e. along a distance of about $6 \mathrm{~km}$ ). Under this regulation, the river bed was strengthened. The projects were designed to accommodate the discharge of high water and to provide residents with better conditions for recreation.

Elblag's environmental plans indicate that, by 2020 , it is planned to regulate much of the remaining part of the Kumiela River, almost to its source (from km 6+124 to $20+097$ of the river course). The cost of this investment was estimated at the level of PLN 20 million (approx. 4.8 million Euro).

The regulation of the river in the urban part is understandable. In such an area, it is necessary to stabilize the bottom, to strengthen the banks and to ensure the appropriate capacity of the river bed storage. However, some regulations, implemented recently, were carried out in undeveloped areas of a recreational nature with walking and cycling paths, where buildings virtually do not exist. Traditional regulation techniques are inadequate there, for example, due to interference in the natural environment but also for aesthetic reasons. Even where such regulations are indeed necessary, one could imagine more environmentally-friendly solutions that do not create barriers between the river and the riparian inhabitants and ecosystems.

Worldwide, there are many cities where rivers have been regulated so much that they not only guarantee fair (even if limited) flood safety, but they also provide conditions for the development of flora and fauna while performing recreational functions for residents on a daily basis. The problem is currently becoming increasingly relevant. Thus, several projects have been devoted to this subject, and the available literature showing examples and methods of solutions has been growing dynamically (Schanze et al. 2004; Bender et al. 2012). In Poland, interesting solutions have been proposed for the city of Łódź (REURIS 2012).

However, the plans for regulating the Kumiela River in its upper course (where it flows through undeveloped areas) are questionable, as the foreseen regulation will
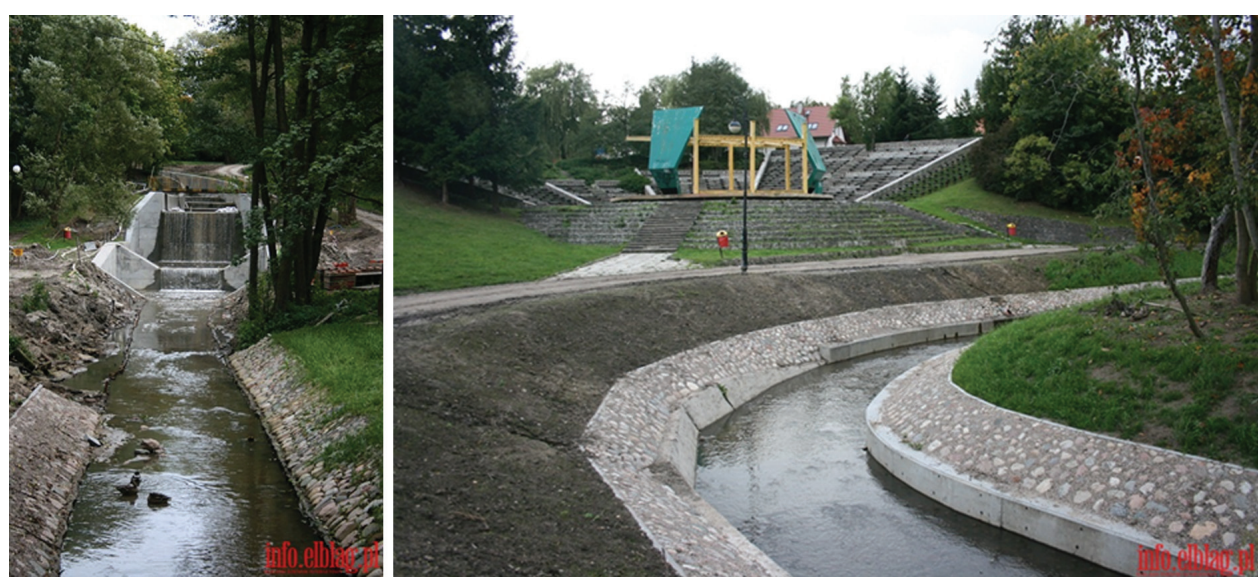

Fig. 2. Examples of the regulations on the Kumiela River in recent years (source: https://info.elblag.pl/galeria,1878,26,39,Regulacjarzeki-Kumieli.html\#szlak) 
very likely aggravate the future flood hazard further downstream in the city.

Because the upper part of the basin is located in the landscape protection area, regulation of the river channel that accelerates the water flow may not be optimal. Reduction of the velocity of water runoff to the riverbed can be more advantageous. It can be achieved by planting appropriate shrubs, afforestation, construction or reconstruction of wetlands, or arrangement of temporary depressions for storing water throughout the catchment (Forbes et al. 2015).

\subsection{Reservoir retention}

The plan for Żuławy (KZGW 2010) and the Water Management Plan (Dz.U. 2016, poz. 1911), which are supported strongly by local authorities, assume the construction of a storage reservoir on the Srebrny Stream (Kumielka), tributary to the Kumiela River. The reservoir is planned to have a total capacity of $116080 \mathrm{~m}^{3}$ and a flood reserve of $26550 \mathrm{~m}^{3}$. The documents do not indicate what effect the reservoir would have on floods of various sizes. However, when comparing the flows for high waters for the Srebrny Stream and the flood capacity (ZZMiUW 2013), it can be stated that a 500-year flood would fill the reservoir in 46 minutes, a 100-year flood in 52 minutes, and a common 2-year flood in 114 minutes. It is clear that the reservoir could only be an effective protection against minor floods. It would definitely not be sufficient for a large flood, such as the one that occurred in 2017, resulting from heavy rainfall that lasted almost two days. In such a case, the impact of the reservoir would be almost negligible. However, it is possible to strengthen the reservoir operation by ensuring natural retention throughout the entire Kumiela River Basin, trying not to increase the sealed area, limiting development, and delaying the flow of rainwater to the river channels in any possible way.

\subsection{Natural retention}

A significant part of the Kumiela River Basin lies within the Landscape Protection Area of the Elbląg Uplands. The landscape arrangement significantly slows down the flow of waters to the riverbed of the Kumiela River Basin. In 2006, the Elbląg City Council approved a local spatial development plan for the Kumiela River corridor (XXVIII/700/2006), the aim of which was to maintain green areas constituting the ecological corridor of the river, as well as "designating attractive locations for new residential and commercial development”. Local spatial development plans have been developed in the last 10 years for an area of over 450 ha of the middle and upper parts of the catchment (XV/310/08, IX/239/2011, XXVI/714/2013). According to these plans, up to $60 \%$ of the area is intended for residential, service and even industrial development. The catchment, whose management and condition impact floods on the Kumiela River and its tributaries, is not subject to as much protection as the river valley. The lack of conditions for rainfall management in the catchment will certainly contribute to accelerating the water flow and will enhance culminations in the river valley.

\subsection{Limiting the exposure to floods}

An important element of the strategy to reduce the flood risk is constraining development that is vulnerable to floods. In the case of urban structures, the possibilities in this respect are limited, but it is possible to restrict the presence of objects particularly sensitive to floods (e.g. hospitals, nurseries, and nursing homes) and to introduce construction rules that render the buildings resistant to flooding. The review of local spatial development plans for the area of the town center, which has been most affected by floods, does not indicate the existence of restrictions on the functions of objects, and no adequate building guidelines are provided. On the contrary, the plan for the Elblag center (X/200/2003) approves the location of such buildings as the hospital, the clinic and the nursing home for mentally handicapped children in the areas directly adjacent to the Kumiela River. This was so even if the names of these streets appeared in information on all past floods.

\subsection{Reducing vulnerability}

In recent years, the city of Elbląg has invested in flood protection, including flood preparation, in various ways. A flood monitoring system has been recently installed, consisting of nine sensors on both the Elbląg River and the Kumiela River. Flood risk maps for the rivers Elbląg, Kumiela and Bobica were also commissioned for eight probabilities of exceedance: $50 \%, 20 \%, 10 \%, 5 \%, 2 \%, 1 \%$, $0.5 \%$, and $0.2 \%$. The aim of these activities was to prepare an operational 24/7 flood forecasting system (Fig. 3) for these areas, based on data from the local water monitoring network and possibly on IMGW-PIB forecasts. However, basing the forecast for a rapid flood on small watercourses (with a culmination time of less than 2 hours) on water level measurements may not be appropriate. It seems that measuring rainfall stations and the use of a rainfallrunoff model could be a better basis for event forecasting. 


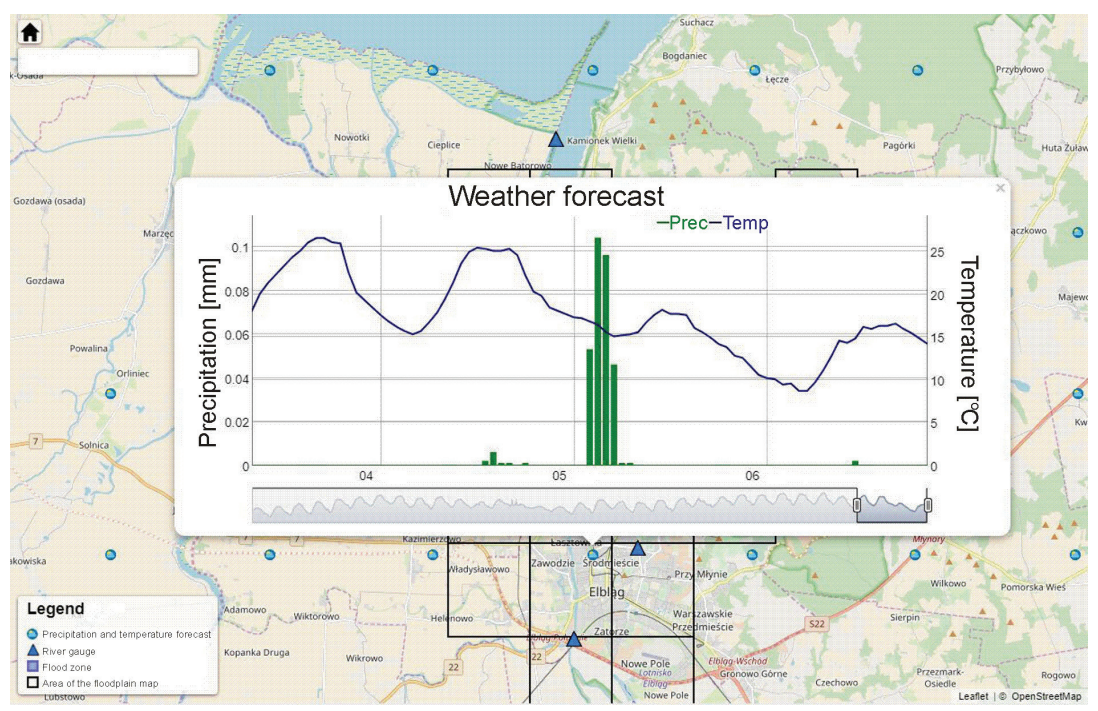

Fig. 3. Output from the operational 24/7 flood forecasting system - Local Flood Risk Monitoring and Support System (LSMZP) for the Municipality of Elbląg

Perhaps a sufficient source of information for a rainfallrunoff model would be data from the IMGW measuring station located in the Kumiela River catchment.

However, the system failed some time before the flood, so it did not provide any assistance during this incident. Access to information about the system can be found at http://185.157.80.212/.

Years ago, the city purchased an SMS notification system for residents. However, the city has not managed to encourage residents to subscribe to this system, which would allow them to be warned with the help of an SMS. Judging by the statements of the authorities, only a small percentage of the endangered people were involved in this system.

Judging by the press coverage, the City and the District of Elbląg try to prepare their services for floods. Training exercises in this area have been quite frequent, taking place in 2009, 2015, and 2017. These exercises included larger exercises for the District of Elbląg, the training of municipal services in the domain of flood prevention including sandbag placement, and training of firefighters and civil defense services.

However, there is no information about actions that prompt residents or administrators of public facilities to prepare themselves for floods. Despite the favorable situation, no information can be found about the educational activities of the city in this topical area, because the Regional Water Management Board in Gdańsk prepared many educational materials and conducted many actions as a part of the flood protection program for the low-lying Żuławy Region that is partly located in a depression below sea level ${ }^{5}$.

Another problem is the apparent lack of preparation of homes and public facilities for the occurrence of a flood. The existing system throughout Poland (not only in Elbląg) does not include measures to assist the owners of endangered houses in preparing for floods, organizing life and work in threatened areas, or improving security. A prominent example is the placement of the hospital's power junction and the installation of dialysis units in the cellars of a hospital located at Lizard Association St. In fact, this area has already been inundated several times in its history. The user of the facility, being extremely vulnerable to flooding, was not really aware that the flood hazard in this location is high. Similar weaknesses pertain to a large number of educational institutions affected by the flood. There are over twenty public facilities functioning in a small area. In any case, the proper arrangement of the function of the premises inside buildings at risk should lead to loss reduction. These examples illustrate that the existing system needs further improvement. The local governments need to increase their efforts to show, remind and educate the local community about places that are potentially endangered by floods so that the people can act adequately in the case of a flood event. Some of them try to improve their safety as much as they can. This finding can be supported by an exemplary statement of a user of an office space at Lizard Association St., published on the Info Elbląg website: »I have no damage, just have to clean up. I worked in this place when the previous flood hit ten years ago. The flood was not as big as it is now, but the damage to my office was much worse because it was flooded all over. Now I have learned the lesson and I knew what to do. I secured the door as well as I could and it turned out that it passed the test ${ }^{6}$. 

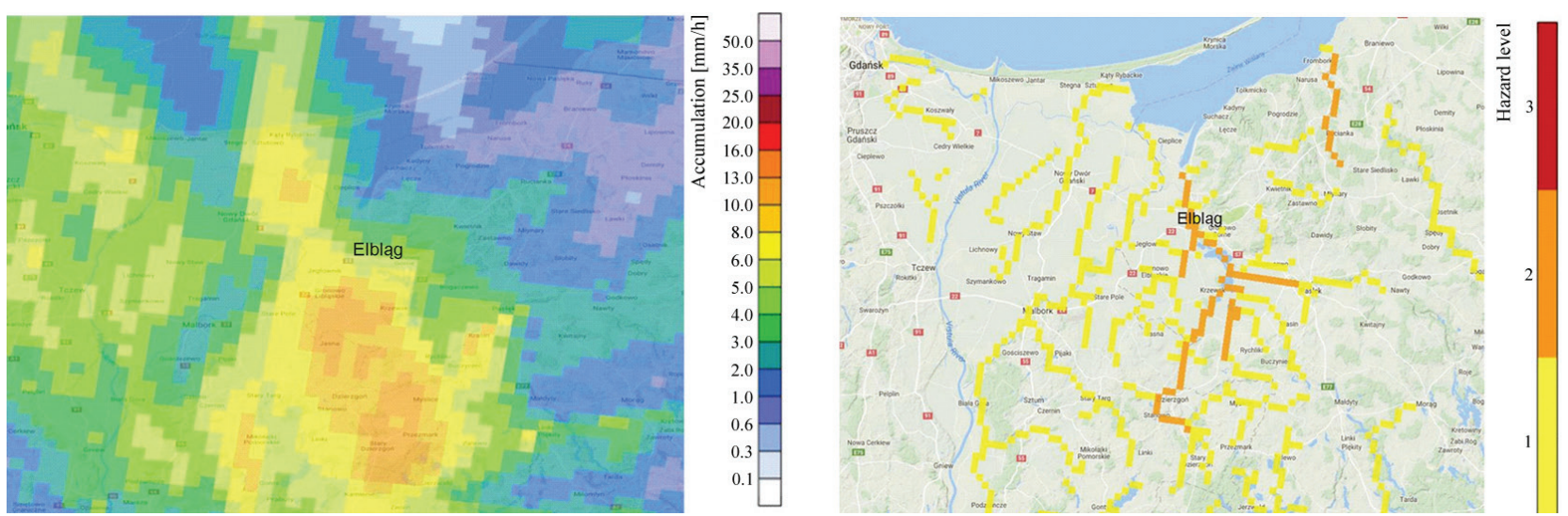

Fig. 4. Radar-based nowcast from 18 September 2017 at 02:00 UTC for 06:00 UTC (left) and associated flash flood hazard indicator (right) for the Elbląg region; estimation of the flash hazard level is based on the radar-based rainfall aggregated on a $1 \mathrm{~km}$ resolution drainage network; the thresholds used for the different hazard levels depend on the regional climatic characteristics and the size of the catchment defined upstream of each point of the drainage network; further information on the methodology is found at www.ericha.eu (source: www.efas.eu).

The attempts of the local authorities to build local flood warning systems, including the installation of their own water monitoring stations and the development of hazard maps for rivers that pose a flood threat to the city, are good steps to reducing flood risk. Using forecasts from European scale systems such as EFAS that aim at providing complementary information and medium-range forecasts (Fig. 4) that could be used as a first, early call for attention, in combination with the National Hydrometeorological Service (IMGW-PIB) forecasts, could provide a good tool for reducing the socio-economic impacts of the floods in Elblag. However, this requires that a well-planned way of informing the population is ensured so that people can act accordingly. The SMS notification system introduced in Elbląg a few years ago has not proved to be effective yet, because the local government did not find the key to persuading the threatened population to subscribe to it and to register. On the contrary, the head of the crisis management of the city of Elblagg issued a statement indicating that they would welcome regulations that render entry of the population into such a system mandatory.

\section{Final remarks}

Making projections of future changes in river flows is a complex task, generating considerable uncertainty. The projected increase in intensity and frequency of extreme precipitation in the future, warmer, climate will exacerbate inundation and flood risk. Piniewski et al. (2017) analyzed projections of changes in high river flow in the Vistula basin, based on results of the EURO-CORDEX experiment under RCP4.5 and RCP8.5 for two time horizons: the near future (2021-2050) and the far future (2071-2100). They found that increases in high flows would dominate in the future. Mean increases in high flows are from $14.4 \%$ (RCP4.5) to $21.0 \%$ (RCP8.5) in the near future and from $23.3 \%$ (RCP4.5) to $36.7 \%$ (RCP8.5) in the far future. This means that the projected increase in high flows is likely to translate into a possible increase of future flood hazard and flood risk. Hence, the present flood risk reduction system is likely to be even less adequate for the future.

In conclusion, events such as the September 2017 flood in Elbląg illustrate some of the shortcomings of the current flood risk management system in Poland. The existing risk management strategy in Poland does not treat losses caused in cities by heavy precipitation as a result of floods, because such events are not floods according to Polish law. On the other hand, the strategy implemented by the national level is based mainly on traditional engineering solutions. The analysis of 25 plans, programs and strategies developed after a large flood in 1997 showed that, apart from a few cases, these documents concerned only technical measures (Konieczny et al. 2006). This was confirmed by a similar analysis carried out on several dozens of plans and programs almost seven years later (KZGW 2013). It showed that out of 1455 activities included in these plans, 1408 refer to flood risk reduction by way of technical (structural) flood protection measures. This can be regarded as a specific feature of the state of consciousness in the countries of Central Europe, which have recently changed the socio-economic system. Traditionally, structural solutions have been dominating in the region, and solutions based on the use of natural features have been downplayed (Loučková 2014). There is a conviction that responsibility for limiting the effects of floods is mainly borne by the central administration and possibly local authorities (Raška 2015).

Inevitably, this pattern of thinking about flood risk reduction is transferred to the level of local authorities and 
individual citizens. The aforementioned analyses prepared for the needs of flood risk management plans (KZGW 2013) clearly showed that, at the communal level (results of surveys from over 850 municipalities in Poland), only those activities that are required by law or are an element of a certain tradition are practically implemented or planned for implementation. The remaining flood risk reduction measures are, in practice, almost absent in local activities.

This explains the rationale for the planned activities in Elbląg. After the September 2017 flood, the city authorities in Elblag intend to build a water storage reservoir on the Srebrny Stream (tributary to the Kumiela), regulate subsequent sections of the Kumiela River, and introduce the obligation to sign in to the SMS notification system.

In the social consciousness, the structural flood defense strategy has become the norm of thinking about methods to reduce the effects of floods. Unfortunately, this does not always contribute to reducing flood damage either locally or nationally. This situation considerably differs from many other towns worldwide, where highly advanced flood preparedness plans exist. For example, in Copenhagen, Rotterdam and Vancouver, there are detailed plans for the preparation for inundations caused by extreme rainfall. They are prepared not only with the intention of limiting the effects of flooding, but also of locally collecting the precious water. The objectives set by the city of Vancouver are aimed at storing up to $90 \%$ of rainfall in the city in the future (Rainwater Management Plan and Green Infrastructure Strategy ${ }^{7}$; Rotterdam Climate Change Adaptation Strategy ${ }^{8}$; The City of Copenhagen Cloudburst Management Plan $\left.{ }^{9}\right)$. There is an interesting integrated approach to flood risk reduction in the city of Ingolstadt, Bavaria, Germany, consisting of natural retention, technical protection (dikes and reservoirs) as well as a non-structural, hydrological protection system ${ }^{10}$.

In Poland, a certain optimism can be related to the currently implemented program Developing adaptation plans for climate change in cities over 100000 residents, whose aim is to work together with local self-governments. Some doubts may arise related to the implementation of such an extensive program in less than two years in as many as 44 cities. However, regardless of program results, it is valuable that the process of discussing climate change and its impact on rain-caused inundations in cities has been initiated at the local level.

\footnotetext{
${ }^{7}$ http://council.vancouver.ca/20160419/document0

${ }^{8}$ http://www.rotterdamclimateinitiative.nl/documents/2015-en-ouder/ Documenten/20121210_RAS_EN_lr_versie_4.pdf

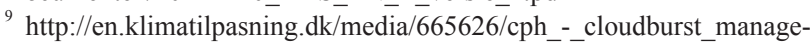
ment plan.pdf

${ }^{10} \mathrm{http}: / /$ www.wwa-ingolstadt.bayern.de/hochwasser/index.htm
}

\section{Acknowledgments}

We would like to acknowledge the information received on this flood event from the Copernicus European Flood Awareness System EFAS. Furthermore, we would like to thank Peter Salamon from the Joint Research Center of the European Commission for his useful comments and valuable feedback on this article.

\section{Bibliography}

IX/239/2011 Uchwała Rady Miejskiej w Elblągu z dnia 27 października 2011 r. w sprawie zmiany miejscowego planu zagospodarowania przestrzennego osiedla Dąbrowa część II, available at http://edzienniki.olsztyn.uw.gov.p1/\#/ legalact/2011/2996/ (data access 19.06.2018)

X/200/2003 Uchwała Rady Miejskiej w Elblągu z dnia 23.10.2003 roku w sprawie miejscowego planu zagospodarowania przestrzennego terenu „Śródmieście - Wschód” w Elblągu, available at http://www.planowanie.umelblag.pl/ files/uchwaly/08.pdf (data access 19.06.2018)

XV/310/08 Uchwała Rady Miejskiej w Elblągu z dnia 26.06.08 r. w sprawie miejscowego planu zagospodarowania przestrzennego osiedla Dąbrowa - cz. I, available at http://www.planowanie.umelblag.pl/files/uchwaly/17.pdf (data access 19.06.2018)

XXVI/714/2013 Uchwała Rady Miejskiej w Elblągu z dnia 14 listopada 2013 r. w sprawie miejscowego planu zagospodarowania przestrzennego rejonu ulicy Królewieckiej, między ulicami Marymoncką, Fromborską a osiedlem Dąbrowa w Elblągu, available at http://edzienniki.olsztyn.uw.gov.pl/ WDU_N/2013/3760/akt.pdf (data access 19.06.2018)

XXVIII/700/2006 Uchwała Rady Miejskiej w Elblągu z dnia 16.02.2006 r. w sprawie miejscowego planu zagospodarowania przestrzennego Doliny rzeki Kumieli w Elblągu, available at http://www.planowanie.umelblag.pl/files/uchwaly/27.pdf (data access 19.06.2018)

2007/60/EC, Directive of the European Parliament and of the Council of 23 October 2007 on the assessment and management of flood risks, EUR-Lex, Brussels

Bender E., Bernardová H., Bigga L., Brejchová E., Brożkowska A., Chalupská H., Commichau S., Czyżewska A., Denysenko S., Gieroszka A., Gryglaszewski K., Holländer R., Kolář P., Kopernik M., Korczak K., Kozłowska B., Krejčí L., Krejčí M., Januchta-Szostak A., Łabaj P., Lange K., Lipiński A., Maceková M., Maier W., Mathea A., Nawrath M., Nissen S., Perečková N., Rybacka B., Trząski L., Valentová P., Weckwert N., 2012, Temat rzeka. Rewitalizacja rzek miejskich: przewodnik praktyczny, REURIS Project, $82 \mathrm{pp}$.

Driessen P.P.J., Hegger D.L.T., Bakker M.H.N., Van Rijswick H.F.M.W., Kundzewicz Z.W., 2016, Toward more resilient 
flood risk governance, Ecology and Society, 21 (4), 53., DOI: 10.5751/ES-08921-210453

Dz.U. 2016, poz. 1911, Rozporządzenie Rady Ministrów z dnia 18 października 2016 r. w sprawie Planu gospodarowania wodami na obszarze dorzecza Wisły, załącznik nr 4, Internetowy System Aktów Prawnych Sejm RP

Forbes H., Ball K., McLay F., 2015, Natural flood management handbook, Scottish Environment Protection Agency, available at https://www.sepa.org.uk/media/163560/sepa-naturalflood-management-handbook1.pdf (data access 19.06.2018)

Graczyk D., Kundzewicz Z.W., 2014, Changes in thermal extremes in Poland, Acta Geophysica, 62 (6), 1435-1449, DOI: $10.2478 / \mathrm{s} 11600-014-0240-7$

Graczyk D., Pińskwar I., Kundzewicz Z.W., Hov Ø., Førland E.J., Szwed M., Choryński A., 2017, The heat goes on - changes in indices of hot extremes in Poland, Theoretical and Applied Climatology, 129 (1-2), 459-471, DOI: 10.1007/s00704-016-1786-x

GUS, 2017, Statystyczne Vademecum Samorządowca 2017 (Statistical Vademecum of Regional Civil Servant 2017), available at https://olsztyn.stat.gov.pl/vademecum/vademecum_warminsko-mazurskie/portrety_miast/miasto_elblag. pdf, (data access 19.06.2018)

Hartmann D.L., Klein Tank A.M.G., Rusticucci M., Alexander L.V., Brönnimann S., Charabi Y., Dentener F.J., Dlugokencky E.J., Easterling D.R., Kaplan A., Soden B.J., Thorne P.W., Wild M., Zhai P.M., 2013, Observations: atmosphere and surface, [in]: Climate Change 2013: The Physical Science Basis. Contribution of Working Group I to the Fifth Assessment Report of the Intergovernmental Panel on Climate Change, T.F. Stocker, D. Qin, G-K. Plattner, M. Tignor, S.K. Allen, J. Boschung, A. Nauels, Y. Xia, V. Bex, P.M. Midgley (eds.), Cambridge University Press, Cambridge, United Kingdom and New York, NY, USA, 159-254

Hay J.E., Easterling D., Ebi K.L., Kitoh A., Parry M., 2016, Conclusion to the special issue: Observed and projected changes in weather and climate extremes, Weather and Climate Extremes, 11, 103-105, DOI: 10.1016/j.wace.2015.11.002

Hegger D.L.T., Driessen P.P.J., Wiering M., Van Rijswick H.F.M.W., Kundzewicz Z.W., Matczak P., Crabbé A., Raadgever G.T., Bakker M.H.N., Priest S.J., Larrue C., Ek K., 2016, Toward more flood resilience: Is a diversification of flood risk management strategies the way forward? Ecology and Society, 21 (4), 52, DOI: 10.5751/ES-08854-210452

IPCC, 2014, Climate Change 2014: Synthesis Report, Contribution of Working Groups I, II and III to the Fifth Assessment Report of the Intergovernmental Panel on Climate Change, Core Writing Team, R.K. Pachauri, L.A. Meyer (eds.), IPCC, Geneva, Switzerland, 151 pp.

Jacob D., Petersen J., Eggert B., Alias A., Christensen O.B., Bouwer L.M., Braun A., Colette A., Déqué M., Georgievski
G., Georgopoulou E., 2014, EURO-CORDEX: new highresolution climate change projections for European impact research, Regional Environmental Change, 4 (2), 563-578, DOI: 10.1007/s10113-013-0499-2

Konieczny R., Madej P., Bogdańska-Warmuz R., Żelaziński J., 2006, Planowanie ograniczania skutków powodzi w Polsce. Ocena dotychczasowych programów, planów i strategii w dorzeczu Wisły, Materiały Badawcze IMGW. Seria Gospodarka Wodna i Ochrona Wód, 22, 70 pp.

Kundzewicz Z.W., Krysanova V., Dankers R., Hirabayashi Y., Kanae S., Hattermann F.F., Huang S., Milly P.C.D., Stoffel M., Driessen P.P.J., Matczak P., Quevauviller P., Schellnhuber H.-J., 2017, Differences in flood hazard projections in Europe - their causes and consequences for decision making, Hydrological Sciences Journal, 62 (1), 1-14, DOI: $10.1080 / 02626667.2016 .1241398$

KZGW, 2010, Program „Kompleksowe zabezpieczenie przeciwpowodziowe Żuław - do roku 2030” zwany „Programem Żuławskim - 2030”. Plan działań dla etapu II (2014-2020), Krajowy Zarząd Gospodarki Wodnej, Warszawa

KZGW, 2013, Analiza obecnego systemu ochrony przeciwpowodziowej na potrzeby opracowania planów zarządzania ryzykiem powodziowym dla obszarów dorzeczy i regionów wodnych, Krajowy Zarząd Gospodarki Wodnej, Warszawa

Lorenc H., Olecka A., 2006, Tendencje występowania opadów o dużym natężeniu w Polsce, [in:] Współczesne problemy klimatu Polski - fakty i niepewności, IMGW, Warszawa, 23-36

Loučková B., 2014, Eastern European perspective on the environmental aspects in current flood risk management: The example of the Czech Republic, [in:] The global water system in the anthropocene, A. Bhaduri, J. Bogardi, J., Leentvaar, S. Marx (eds.), Springer International Publishing, 183-195

Łupikasza E., 2017, Seasonal patterns and consistency of extreme precipitation trends in Europe, December 1950 to February 2008, Climate Research, 72 (3), 217-237, DOI: $10.3354 /$ cr01467

Majewski W., 2016, Urban flash flood in Gdańsk - 2001. Case study, Meteorolology Hydrology and Water Management, 4 (2), 41-49, DOI: 10.26491/mhwm/64636

Mezghani A., Dobler A., Haugen J.E. Benestad R.E., Parding K.M., Piniewski M., Kardel I., Kundzewicz, Z.W., 2017, CHASE-PL Climate Projection dataset over Poland - bias adjustment of EURO-CORDEX simulations, Earth System Science Data, 9 (2), 905-925, DOI: 10.5194/essd-9-905-2017 Owczarek M., Filipiak J., 2016, Contemporary changes of thermal conditions in Poland, 1951-2015, Bulletin of Geography. Physical Geography Series, 10, 31-50, DOI: 10.1515/bgeo2016-0003 
Piniewski M., Szcześniak M., Kundzewicz Z.W., Mezghani A., Hov Ø., 2017, Changes in low and high flows in the Vistula and the Odra basins: Model projections in the European scale context, Hydrological Processes, 31 (12), 2210-2225, DOI: $10.1002 /$ hyp. 11176

Pińskwar I., Choryński A., Graczyk D., Kundzewicz Z.W., 2018, Observed changes in extreme precipitation in Poland: 19912015 versus 1961-1990, Theoretical and Applied Climatology, DOI: 10.1007/s00704-018-2372-1

Pińskwar I., Dobler A., 2018, Observed and projected changes in heavy precipitation in Poland, prepared to submitting

Priest S.J., Suykens C., Van Rijswick H.F.M.W., Schellenberger T., Goytia S.B., Kundzewicz Z.W., Van Doorn-Hoekveld W.J., Beyers J.-C., Homewood S., 2016, The European Union approach to flood risk management and improving societal resilience: lessons from the implementation of the Floods Directive in six European countries, Ecology and Society, 21 (4), 50, DOI: 10.5751/ES-08913-210450

Radziejewski M., Kundzewicz Z.W., 2000, Hydrospect Software for detecting changes in hydrological data, [in:] Detecting trend and other changes in hydrological data, Z.W. Kundzewicz, A. Robson (eds.), WMO/TD-No. 1013, World Meteorological Organization, Geneva, 151-152

Raška P., 2015, Flood risk perception in Central-Eastern European members states of the EU: a review, Natural Hazards, 79 (3), 2163-2179, DOI: 10.1007/s11069-015-1929-x

REURIS, 2012, Urban rivers - vital spaces. Manual for urban river revitalization: implementation, participation, benefits, E. Bender, L. Bigga, W. Maier (eds.), Revitalization of Urban River Spaces Project (REURIS), available at http://www.
upv.es/contenidos/CAMUNISO/info/U0643715.pdf (data access 19.06.2018)

Schanze J., Olfert A., Tourbier J.T., Gersdorf I., Schwager T., 2004, Existing urban river rehabilitation schemes. Final report in Work Package 2, Urban River Basin Enhancement Methods project (URBEM), available at http://www.urbem. net/WP2/WP2_case_studies.pdf (data access 19.06.2018)

Van Vuuren D.P., Edmonds J., Kainuma M., Riahi K., Thomson A., Hibbard K., Hurtt G.C., Kram T., Krey V., Lamarque J.-F., Masui T., Meinshausen M., Nakicenovic N., Smith S.J., Rose S.K., 2011, The representative concentration pathways: An overview, Climatic Change, 109 (1-2), 5-31, DOI: 10.1007/s10584-011-0148-z

Wibig J., 2018, Heat waves in Poland in the period 1951-2015: trends, patterns and driving factors, Meteorology Hydrology and Water Management, 6 (1), 37-45, DOI: 10.26491/ mhwm/78420

Wibig J., Jakusik E. (eds.), 2012, Wpływ zmian klimatu na środowisko, gospodarkę i społeczeństwo. Vol. 1: Warunki klimatyczne i oceanograficzne w Polsce i na Bałtyku południowym. Spodziewane zmiany i wytyczne do opracowania strategii adaptacyjnych w gospodarce krajowej, IMGW-PIB, Warszawa, 283 pp.

ZZMiUW, 2013, Raport oceny oddziaływania na środowisko dla przedsięwzięcia „Aktualizacja dokumentacji projektowej wraz z nadzorem autorskim pn. Regulacja Srebrnego Potoku $\mathrm{km} 0=000-12+167$ miasto Elbląg, gmina Milejewo woj. warmińsko-mazurskie”, Żuławski Zarząd Melioracji i Urządzeń Wodnych w Elblągu, available at um-elblag.samorzady. $\mathrm{pl} /$ zalacznik/id/26152 (19.06.2018) 